Volume 2 Number 2 March 2019

\title{
CEMENT ADDITIVE USE REDUCTION FACTORS TO IMPROVING THE QUALITY CONCRETE BIOCONC
}

\author{
'Muhammad chabibullah, ${ }^{2}$ Tony Hartono Bagio \\ Narotama University \\ muhammadchabib26@gmail.com
}

\begin{abstract}
Technology applications in the concrete mix is growing very rapidly in this modern era to obtain concrete results with characteristics that are environmentally friendly and non-toxic. Bioconc is innovation in developing green technology with the insertion of a micro-gap or slit gradation mycelia microbe as a micro-filter to mengoptimalkanatau reduce the amount of cement concrete on the concrete mix in total will increase the efficiency in the concrete and reduce the material components of the most expensive in the concrete, the cement. in job mix additive Bioconc require $\mathrm{R} \%$, ie a reduction factor of cement that will determine how the dose of cement and dose additive Bioconc, and therefore to seek $\mathrm{R} \%$ require some percentage of reduction factor of cement optimum ranging from the concrete Normal, $5 \%, 10 \%, 15 \%, 20 \%, 25 \%, 30 \%, 35 \% .^{5}+$ $31271 x^{4}-4709 x^{3}-233.1 x^{2}+79.66 x+22: 18$, concrete quality obtained from normal concrete with $\mathrm{fc}^{\prime}=20 \mathrm{MPa}$ generate optimum value reduction of cement amounted to $28.869 \%$.
\end{abstract}

Keywords: Cement reduction factor, Bioconc

\section{INTRODUCTION}

Modern technology and sophisticated growing rapidly especially in the world of construction. One of the factors determining a structure in carrying static and dynamic loads, is the quality of materials pembentuknya.Beton is the most popular components used in the construction of building structures and many many experienced improvement in terms of strength, age, benefits and costs. It is known that the strength of concrete is heavily influenced by its constituent material composed of sand, stone aggregate, cement, water and other mixed materials. Improving the quality of the concrete mix will improve also the quality of concrete compressive strength. One way to improve the quality of the concrete mix is to use additional materials either synthetic or organic such as eg Bioconc. Bioconc is Bio-technology product is made from organic or natural materials, denatured proteins, biopolymers and mineral surfactant organic fermented by beneficial microbes. Bioconc is the performance of some microbes with dissolved nutrients, which will start working when, there is a supply of oxygen (aerobic process) and microbial performance ended when the concrete has reached the ultimate setting time, where there is no supply of oxygen again, and microbes in a state of dormant (sleeping). The microbial population growing exponentially over time. 
Volume 2 Number 2 March 2019

Bioconc treat mixed concrete by inserting a space gap between fine aggregate and coarse aggregate were biyasanya filled Portland cement as a bonding agent, so that will reduce the amount of cement needed.

\section{RESEARCH METHODS}

Concrete is a mixture of portland or other hydraulic cement, fine aggregate, coarse aggregate and water, with or without additional mixed material forming a mass padat.Agregat - other aggregates are mixed together with a paste made of cement and water to form a time-like rock and tekadang using other mixed materials (admixture or additive). Material or material that is used among other things:

1. Cement

The results from a combination of industrial raw materials limestone / lime as the main material and lempunung / clay or other substitute material with the final result of the solids in powder form (bulk). Definition of portland cement is a hydraulic cement produced by grinding slag portland cement mainly composed of calcium silicate which is hydraulic and ground together with other additives such as one or more of the crystalline form of compound calcium sulfate and may be combined with other additives.

2. Aggregate

Aggregate is hard or stiff material concrete apartment blocks that percentage is most banyakmendominasi and can be derived from organic materials or inorganic. The volume of aggregate in the concrete occupy about $70 \%-75 \%$, so the quality is very influence untun aggregate concrete quality. Aggregates are divided into two namely fine aggregate and coarse aggregate, wherein the block making agragat used is fine aggregate that passes 12 sieve with a diameter of $4.75 \mathrm{~mm}$ and retained on $0.063 \mathrm{~mm}$ sieve.

\section{Water}

The water used in the concrete mix should qualify C1602M ASTM standards. Mixing water used in prestressed concrete or concrete in which aluminum metal is embedded, including free water contained in the aggregate, may not contain chloride ions in the amount of harmful (SNI-25-BSN 2013).

\section{Effect of Microbes}

Microbes are organisms that are small or micro. microbes can perform activities for life. Belonging to the prokaryotes such as bacteria, viruses, and eukaryotes such as algae, protozoa. Microbes play an important role in his life (Nester, Anderson, Robert, Nester, 2009). Microbes composed of bacteria, fungi, and viruses. In general, each microbe has morphological and anatomical structure of different (Waluyo, 2004). The primary role of microbes are decomposers of organic material. Besides harmful, microbes also has many benefits for humans and the environment. Microbes do not need a big place, easily grown in artificial media such as the presence of air and pembiakannya level relatively quickly. Therefore, each microbe has a role or influence in the life (Darkuni, 
Volume 2 Number 2 March 2019

2001). Mikrobakteri used Bioconc enzyme, which is a product made from Bioconc organik.Enzim material is environment-friendly products, non-toxic, and safe for humans and other living creatures. Bioconc enzymes can also increase the compressive strength, reduce the weight of the cement, and reduce shrinkage cracks (Basoeki Makno, 2001). Microbes work "aerobic" and optimal work at room temperature $30^{\circ} \mathrm{C}$, and will be dormant when in a room with a temperature of $60^{\circ} \mathrm{C}$ and above. Likewise, when are diruang without supply of oxygen, the microbes will be dormant or "sleep", as long as the packaging, before it is used. Shortly after these microbes are released (out of the packaging to be mixed into the concrete mix), then the microbes multiply rapidly and produce mycelia quickly to concrete, to fill the gap gradation which is usually filled with cement paste, so that the cement content is reduced. Along with the gap being filled mycelia gradation by microbes, the surface area increases tied to the cement paste (coupled with the microbe mycelia) which is correlated to the quality of concrete (concrete strength). When the concrete hydration process reaches a temperature of $60^{\circ} \mathrm{C}$, the microbes will be dormant, and when the setting time of concrete has been achieved, and the supply of oxygen to the microbes have been isolated, the microbes will be dormant (Basoeki Makno, 2001).

The characteristics of the microbes mycelia (Basoeki Makno, 2001):

- $\quad$ The diameter of between $5 \mu \mathrm{m} \mathrm{s} / \mathrm{d} 10 \mu \mathrm{m}$ - Length between $5 \mu \mathrm{m} \mathrm{s} / \mathrm{d} 30 \mu \mathrm{m}$

- $\quad$ Growth speed sd 10,000,000 125,000,000 per day

- Temperature survival for life is the temperature of the room $\mathrm{s} / \mathrm{d} 60^{\circ} \mathrm{C}$ that occur in the process of setting concrete 1 hour ( 2 hours setting time of concrete with concrete transportation process assuming 1 hour, so stay 1 hour process.

- $\quad$ Reduce heat - Menginsersi concrete gradation gap usually filled the cement paste.

Reduce shrinkage cracks, indicated the pattern of cracked concrete when done crushing concrete cube test as a comparison photo cube with treatment and without treatment.

\section{RESEARCH RESULT}

After laboratory tests on the materials used, made with standard concrete mix design according to ISO 7656-2012 in Table 1 below:

Table 1: Normal Form Concrete mortar stats

\begin{tabular}{|c|l|l|}
\hline No. & \multicolumn{1}{|c|}{ Commentary } & \multicolumn{1}{c|}{ Value } \\
\hline 1 & $\begin{array}{l}\text { The compressive strength which would } \\
\text { otherwise require }\end{array}$ & $20 \mathrm{MPa}$ at 28 days (cylinder) \\
\hline 2 & Standard deviation & 4 \\
\hline 3 & The additional value (margin) & $1.64 \times 4=6.56$ \\
\hline 4 & Target compressive strength & $26.56 \mathrm{MPa}$ \\
\hline 5 & Portland cement type & Gresik OPC \\
\hline
\end{tabular}


Volume 2 Number 2 March 2019

\begin{tabular}{|c|l|l|}
\hline 6 & Type of coarse aggregate & Broken stone Mojokerto \\
\hline 7 & Type smooth agreat & natural Lumajang \\
\hline 8 & Factor cement water & $0: 54$ \\
\hline 9 & Density cement & $3: 15 \mathrm{TYPE}$ I \\
\hline 10 & slump & $75-100 \mathrm{~mm}$ \\
\hline 11 & The maximum aggregate size & $19 \mathrm{~mm}$ \\
\hline 12 & Air content & $2 \%$ \\
\hline 13 & Free water content & $205 \mathrm{Ltr}$ \\
\hline 14 & Cement content & $349 \mathrm{~kg}$ \\
\hline 15 & Fas adjusted & $205 \mathrm{Ltr}$ \\
\hline 16 & The composition of the granular aggregate & ZONE II \\
\hline 17 & Weight of fresh concrete & $2373 \mathrm{~kg} / \mathrm{m}^{3}$ \\
\hline 18 & The combined aggregate levels & $1810 \mathrm{~kg} / \mathrm{m}^{3}$ \\
\hline 19 & Levels of fine aggregate & $875 \mathrm{~kg} / \mathrm{m}^{3}$ \\
\hline 20 & Levels of coarse aggregate & $935 \mathrm{~kg} / \mathrm{m}^{3}$ \\
\hline
\end{tabular}

Source: Calculation Results

The proportion of normal concrete mix above is also used to make by using different Bioconc with the required proportion of cement or cement-called reduction factor. Bioconcyang used are brand Bioconc of PT. Bangun Mukti Abadi. As for job-mix calculation using Bioconc by the formula.

Table 2 Job-Mix using Bioconc

\begin{tabular}{|c|c|c|c|}
\hline \multicolumn{4}{|c|}{ MODIFICATION OF JOB MIX NFA (Non Fly Ash) with Additive BIOCONC } \\
\hline \multicolumn{3}{|c|}{ Cement Reduction Factor } & $\mathbf{R} \%$ \\
\hline \multicolumn{3}{|c|}{ Job Mix Concrete Grade } & G \\
\hline \multicolumn{3}{|c|}{ Job Volume Mix } & $1 \mathrm{~m} 3$ \\
\hline No. & material Mix & NFA & $\begin{array}{c}\text { Modifications Job-Mix Cement } \\
\text { Bioconc Reduction (R\%) }\end{array}$ \\
\hline 1 & Cement & A & $A^{*}(1-R \%)$ \\
\hline 2 & Water & B & $\mathrm{B}^{*}(1-\mathrm{R} \%)$ \\
\hline 3 & Coarse Aggregates & $\mathrm{C}$ & $C+\left((A+B) * R \%{ }^{*}(C /(C+E))\right)$ \\
\hline 4 & Fine aggregate & $\mathrm{D}$ & $\mathrm{D}+\left((\mathrm{A}+\mathrm{B}){ }^{*} \mathrm{R} \%{ }^{*}(\mathrm{E} /(\mathrm{C}+\mathrm{E}))\right)$ \\
\hline 5 & Bioconc & - & 500 \\
\hline & TOTAL WEIGHT & & $A+B+C+D+500 c c$ \\
\hline
\end{tabular}

Here is the composition of the normal plan per m3 of concrete constituent material used:

$\begin{array}{lll}\text { Cement } & : 349 & \mathrm{~kg} / \mathrm{m}^{3} \\ \text { Water } & : 214 & \mathrm{~kg} / \mathrm{m}^{3} \\ \text { Coarse aggregate } & : 935 & \mathrm{~kg} / \mathrm{m}^{3} \\ \text { fine aggregate } & : 875 & \mathrm{~kg} / \mathrm{m}^{3} \\ \text { Bioconc } & : 500 & \mathrm{ml} / \mathrm{m}^{3}\end{array}$


Volume 2 Number 2 March 2019

Cement reduction factor

$\begin{array}{ll}\text { sample I } & \text { Normal } \\ \text { sample II } & 5 \% \\ \text { sample III } & 10 \% \\ \text { samples IV } & 15 \% \\ \text { sample V } & 20 \% \\ \text { samples VI } & 25 \% \\ \text { samples VII } & 30 \% \\ \text { sample VIII } & 35 \%\end{array}$

After testing and evaluation laboratory average compressive strength of each sample type or concrete, following the recapitulation of the compressive strength of concrete cylinders age of 28 days, in Table 3 :

Table 3 Summary of Results of Concrete Compressive Strength

\begin{tabular}{|c|c|c|c|c|c|c|c|c|}
\hline \multirow[t]{2}{*}{ Variation } & \multirow[t]{2}{*}{$\begin{array}{c}\text { test } \\
\text { specime } \\
n\end{array}$} & Weight & Diameter & High & $\begin{array}{l}\text { load } \\
\text { tap }\end{array}$ & $\begin{array}{c}\text { A } \\
\text { Cross- } \\
\text { sectional } \\
\text { area }\end{array}$ & $\begin{array}{l}\text { The } \\
\text { results of } \\
\text { compres } \\
\text { sive } \\
\text { strength }\end{array}$ & $\begin{array}{c}\text { Avera } \\
\text { ge }\end{array}$ \\
\hline & & G & $M$ & $\mathrm{M}$ & kN & $\mathrm{m}^{3}$ & Мpa & Mpa \\
\hline \multirow{3}{*}{$\begin{array}{c}\text { normal } \\
\text { concrete }\end{array}$} & sample 1 & 12512 & 0.15 & 0.30 & 400 & 0.01766 & 22.64 & \multirow{3}{*}{22.16} \\
\hline & sample 2 & 12500 & 0.15 & 0.30 & 380 & 0.01766 & 21,50 & \\
\hline & sample 3 & 12516 & 0.15 & 0.30 & 395 & 0.01766 & 22.35 & \\
\hline \multirow{3}{*}{$\begin{array}{l}5 \% \text { (a } \\
\text { reduction } \\
\text { factor of } \\
\text { cement) }\end{array}$} & sample 1 & 12450 & 0.15 & 0.30 & 435 & 0.01766 & 24.62 & \multirow{3}{*}{25.27} \\
\hline & sample 2 & 12509 & 0.15 & 0.30 & 450 & 0.01766 & 25.46 & \\
\hline & sample 3 & 12449 & 0.15 & 0.30 & 455 & 0.01766 & 25.75 & \\
\hline \multirow{3}{*}{$\begin{array}{c}10 \% \\
\text { (cement } \\
\text { reduction } \\
\text { factor) }\end{array}$} & sample 1 & 12598 & 0.15 & 0.30 & 455 & 0.01766 & 25.75 & \multirow{3}{*}{25.46} \\
\hline & sample 2 & 12506 & 0.15 & 0.30 & 460 & 0.01766 & 26.03 & \\
\hline & sample 3 & 12446 & 0.15 & 0.30 & 435 & 0.01766 & 24.62 & \\
\hline \multirow{3}{*}{$\begin{array}{c}15 \% \\
\text { (cement } \\
\text { reduction } \\
\text { factor) }\end{array}$} & sample 1 & 12610 & 0.15 & 0.30 & 440 & 0.01766 & 24.90 & \multirow{3}{*}{25.28} \\
\hline & sample 2 & 12544 & 0.15 & 0.30 & 460 & 0.01766 & 26.03 & \\
\hline & sample 3 & 12641 & 0.15 & 0.30 & 440 & 0.01766 & 24.90 & \\
\hline \multirow{3}{*}{$\begin{array}{c}20 \% \\
\text { (cement } \\
\text { reduction } \\
\text { factor) }\end{array}$} & sample 1 & 12520 & 0.15 & 0.30 & 430 & 0.01766 & 24.33 & \multirow{3}{*}{24.52} \\
\hline & sample 2 & 12506 & 0.15 & 0.30 & 445 & 0.01766 & 25.18 & \\
\hline & sample 3 & 12512 & 0.15 & 0.30 & 425 & 0.01766 & 24.05 & \\
\hline \multirow{3}{*}{$\begin{array}{c}25 \% \\
\text { (cement } \\
\text { reduction } \\
\text { factor) }\end{array}$} & sample 1 & 12571 & 0.15 & 0.30 & 465 & 0.01766 & 26.31 & \multirow{3}{*}{26.23} \\
\hline & sample 2 & 12478 & 0.15 & 0.30 & 450 & 0.01766 & 25.46 & \\
\hline & sample 3 & 12674 & 0.15 & 0.30 & 475 & 0.01766 & 26.87 & \\
\hline
\end{tabular}


IJTI (International Journal Of Transportation And Infrastruct ure) Available Online @ http://jumal.na rota ma.ac.id/index.php/ijti ISSN : 2597-4769 (ONUNE) ISSN : 2597-4734 (CETAK)

Volume 2 Number 2 March 2019

\begin{tabular}{|c|l|l|l|l|l|l|l|l|}
\hline $\begin{array}{c}30 \% \\
\text { (cement }\end{array}$ & sample 1 & 12537 & 0.15 & 0.30 & 525 & 0.01766 & 29.71 & \\
\cline { 2 - 9 } $\begin{array}{c}\text { reduction } \\
\text { factor) }\end{array}$ & sample 2 & 12550 & 0.15 & 0.30 & 500 & 0.01766 & 28.29 & \multirow{2}{*}{26.88} \\
\cline { 2 - 9 } & sample 3 & 12639 & 0.15 & 0.30 & 400 & 0.01766 & 22.64 & \\
\hline $\begin{array}{c}35 \% \\
\text { (cement } \\
\text { reduction } \\
\text { factor) }\end{array}$ & sample 1 & 12356 & 0.15 & 0.30 & 355 & 0.01766 & 20.09 & \\
\cline { 2 - 9 } & sample 2 & 12521 & 0.15 & 0.30 & 365 & 0.01766 & 20.65 & \multirow{2}{*}{20.18} \\
\cline { 2 - 9 } & sample 3 & 12089 & 0.15 & 0.30 & 345 & 0.01766 & 19.52 & \\
\hline
\end{tabular}

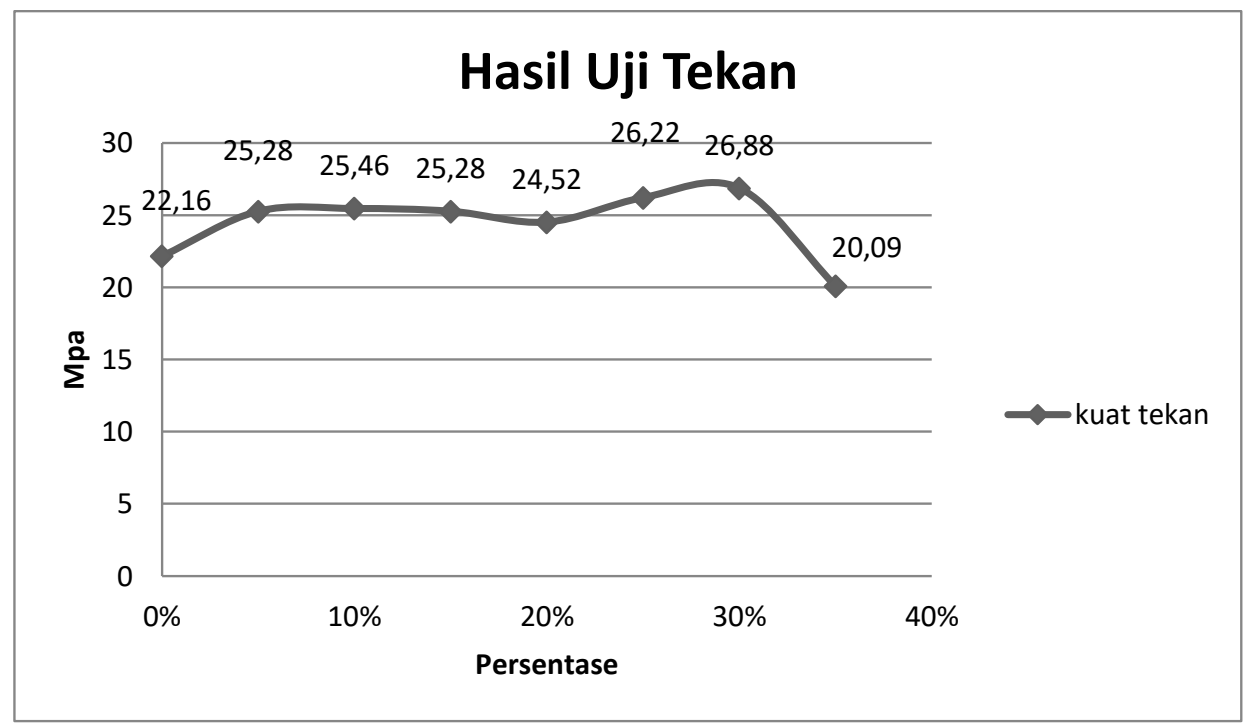

Figure 1 Pattern Strength Concrete

The statistical analysis used seek optimum levels of cement reduction factor for compressive strength of concrete is the rank of polynomial regression analysis. In this study, the variable $(x)$ is a free variation reduction factor of cement and the dependent variable $(y)$ is the compressive strength of concrete. Rank regression analysis are presented in the following figure: 
Volume 2 Number 2 March 2019

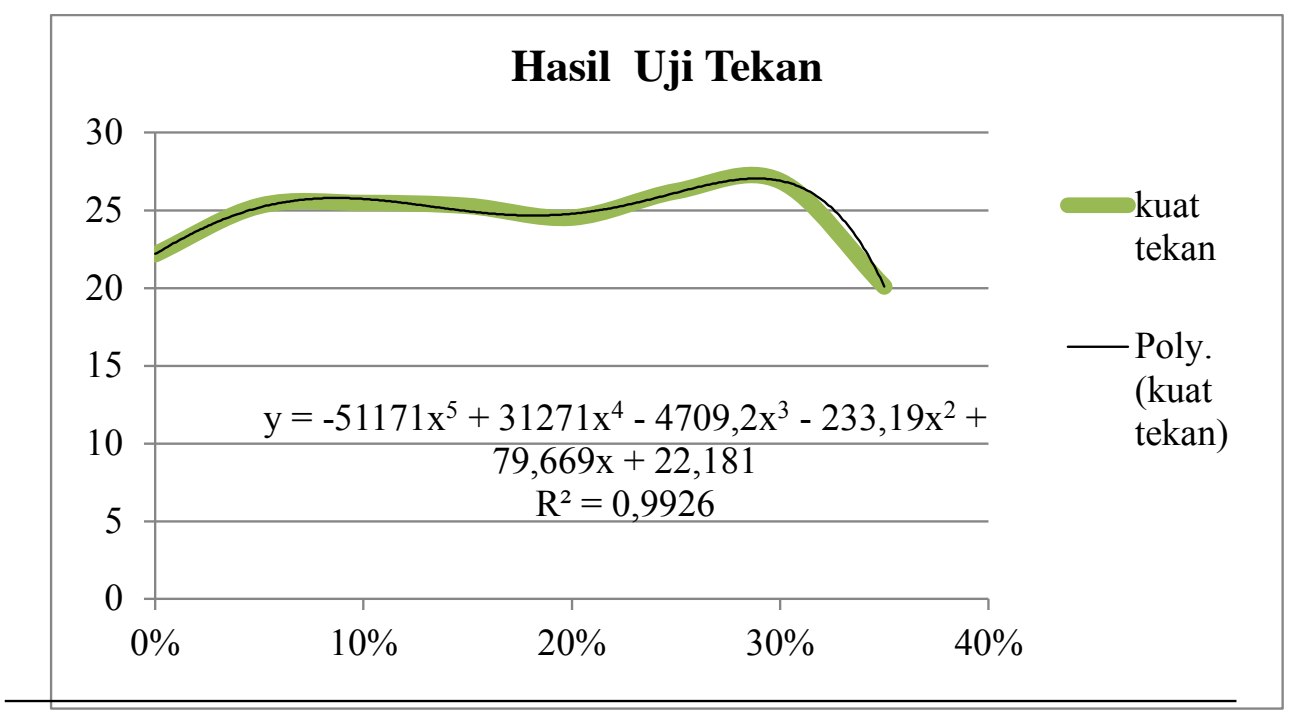

Figure 2 Rank polynomial regression analysis

From the graph above unknown polynomial regression equation squared as follows:

$f(x) \quad=-51171 x^{5}+31271 x^{4}-4709 x^{3}-233,1 x^{2}+79,66 x+22.18$

$=79.66-466,2 x-23545 x 125084 x^{\wedge} 2+\wedge 3-555855 x^{\wedge} 4$

with $\mathrm{R}^{2}=0.992$

$$
\begin{aligned}
& x 1=-0.0683559 \\
& x 2=0.086832 \\
& x 3=0.181725 \\
& x 4=0.288685
\end{aligned}
$$

Based on a graphic image 2, the calculation of the rank of polynomial regression equation, it can be inferred by knowing the results of the optimum percentage reduction factor Bioconc cement additive additions that can add concrete power amounted to $28.869 \%$. So generated in this study are looking for optimum cement reduction factor $(\mathrm{R} \%)$ is equal to $28.869 \%$ or equal to $30 \%$.

\section{CONCLUSION}

1. From the results of the test laboratory material fineness modulus of fine aggregate 3 , specific gravity (SSD) $2.36 \mathrm{~g}$, absorption (absorption) $1.22 \%$ water, moisture or water content of $1.69 \%$, and coarse aggregate density (SSD) 2, 56 $\mathrm{gr}$, absorption (absorption) of water $1.8 \%$, dry weight of $1522 \mathrm{~g}, 19 \mathrm{~mm}$ aggregate size, moisture or water content of $0.4 \%$. Mix in the design calculations for normal concrete admixture $1 \mathrm{~m}^{3}$ of his matches are 214 water, $349 \mathrm{~kg}$ of cement, coarse aggregate $935 \mathrm{~kg}$ wet, wet dry aggregate $875 \mathrm{~kg}$. And Job Mix Bioconc cement reduction factor there are several variations ranging from $0 \%, 5 \%, 10 \%, 15 \%$, $20 \%, 25 \%, 30 \%, 35 \%$. 
Volume 2 Number 2 March 2019

2. From the results of the compressive strength test to look for cement reduction factor an average of three samples with a variation of $0 \%$ at $22.16 \mathrm{MPa}, 5 \%$ at $25.27 \mathrm{MPa}, 10 \%$ at $25.46 \mathrm{MPa}, 15 \%$ of $25.28 \mathrm{MPa}, 20 \%$ of $24.52 \mathrm{MPa}, 25 \%$ at $26.23 \mathrm{MPa}, 30 \%$ at $26.88 \mathrm{MPa}$, and $35 \%$ of $20.18 \mathrm{MPa}$. Calculation of polynomial equations rank test results press $f(x)=-51171 x^{5}+31271 x^{4}-4709, x^{3}-233,1 x^{2}+$ $79,66 x+22.18$ with derivatives

$f^{\prime}(x)=-255,855 x^{4}+125084 x^{3}-14127 x^{2}-466.2+79.66$ And $R^{2}=0.992$ then obtained $x 1=-0.0683559, x 2=0.086832,0.181725=x 3, x 4=0.288685$. So the results of this research to get the percentage of cement optimum reduction factor amounted to $28,869 \%$ or $30 \%$ to increase the compressive strength of concrete with the addition of additive Bioconc.

\section{REFERENCES}

Annas, Azwar. Utilization mikrobakteri On With High Quality Concrete Additional silicafume.Surabaya. 2015.

National Standardization Agency of Indonesia (SNI), Procedure for Making Plans Mixed Concrete NormalSNI 03-2834-2000, adobsi SK-SNI T-15 1990-03. 2000.

Basoeki, Makno. Against Bioconc Performance Concrete Quality Improvement. 2001.

Mulyono, Tri. Concrete Technology. Yogyakarta. 2004.

Pradana Sofyan Ali. Tony Hartono Bagio. Analysis on compressive strength of Concrete Optimum with the addition Bioenzym, Thesis Civil Engineering

Department, Faculty of Engineering, University of Narotama. 2016. 